\title{
Fortifications at Piacenza. Historical background, restoration, open-air museum and urban planning
}

\section{Francesco Broglia}

Università eCampus, Novedrate (Como), Italy, architettofrancescobroglia@gmail.com

\begin{abstract}
The "modern" fortifications at Piacenza are situated at a significant physical and cultural crossroads linking the Mediterranean and roads leading to Central Europe and the North Sea. This paper aims to include their historical bastion features and city walls within an open-air educational museum that is well integrated within the modern town. Starting from the original basis of a defensive nature conceived to mark boundaries and divide kingdoms, the plan is to build a park which, by means of a fully-equipped green belt, is able to narrate the story of the Siegecraft and Renaissance apse techniques. At the same time, the aim is to explain how such a system may serve as a valuable means of allowing sustainable urban transport along with that of respecting and highlighting cultural heritage. In order to tell the complete story, an attempt is made to describe how direct relief may relate to the "compact town".
\end{abstract}

Keywords: Fortifications, history, restoration, urban project.

\section{Introduction}

The City of Piacenza is endowed with an ancient system of "modern-style" fortifications dating back to the Renaissance. This system, conceived and realized on the basis of a unitary project, maintains to this day a certain integrity of the whole, despite the aggravations of men and time. This walled bastion did not emerge from the turbulence of the movements for the Unification of Italy period unscathed; after having joined the Kingdom of Italy, became the object of building speculation. The yearning for urban expansionism, at the turn of the nineteenth and twentieth centuries, led the Emilian town to formulate plans that foresaw the demolition of the ancient ramparts to make way for main through roads and railway stations; such actions were also performed in other European towns. That city walls, in European towns, with the advent of national liberal states and with the industrial revolution, were seen as constricting elements of urban development, is well known.

The bastions in particular, taking the form of large, fixed and low-level extended military weapons, occupy considerable surfaces. Rendered redundant by Napoleonic war techniques, based on large-scale manoeuvres and open-field battles, they were seen as unnecessary and cumbersome constructions. It should be added that their conception was linked to the political and military protagonists of the Ancien Régime, and lack of interest, if not aversion, for similar constructions is fully understood. The powerful polygonal geometries constituted the physical and ideal limit of the town ${ }^{1}$. A real safe haven of absolute power. The constitution of sixteenthcentury principalities coincides with the invention of the bastion ${ }^{2}$ and the construction of for- 
tresses able to defend themselves and to attack with firearms (Artocchini, 1983).

On the contrary, the birth of urbanism as a positivist science about three hundred years later corresponds to the development of programs aimed at destroying the fortresses of the sixteenth century (Cerdà, 2004), according to ideas of open towns, in full physical and economic expansion $^{3}$. In an Enlightenment and mercantilist vision, the Renaissance walls are an obstacle and their set of standards an impediment. The "dictates" of the Lords, of "Machiavellian" memory, required the maintenance of large unbuilt spaces (Hogg, 1982), both in the pomerium $^{4}$, and in front of the firing stations. Widespread cutting or the systematic destruction of trees, orchards, buildings and artefacts, kept the cannons' firing zones clear. These areas, open fields in the throes of the Industrial Revolution, were to become precious for setting up industrial plants, building out transport routes, hosting government departments and places of social and business interaction. In practice, the concept of the town first affirms itself thanks to its defensive walls, as a break with the countryside; subsequently, almost three centuries later, it was to emerge as an open system in continuous growth.

\section{Characters and history of Piacenza forti- fied walls}

Three events modified fortified walls of Italian towns following the proclaimed unity of the nation. The most common one was partial or total demolition to make way for the construction of buildings, road bypasses or railway junctions. The second was that of militarization, that is to say fortresses were included within the perimeter of barracks, warehouses and logistic centres of the army. The third, of ennobling style (for that time), consisted of transformation into gardens and public promenades with flower beds and tall trees. The Bastions of Piacenza experienced all three modus operandi.

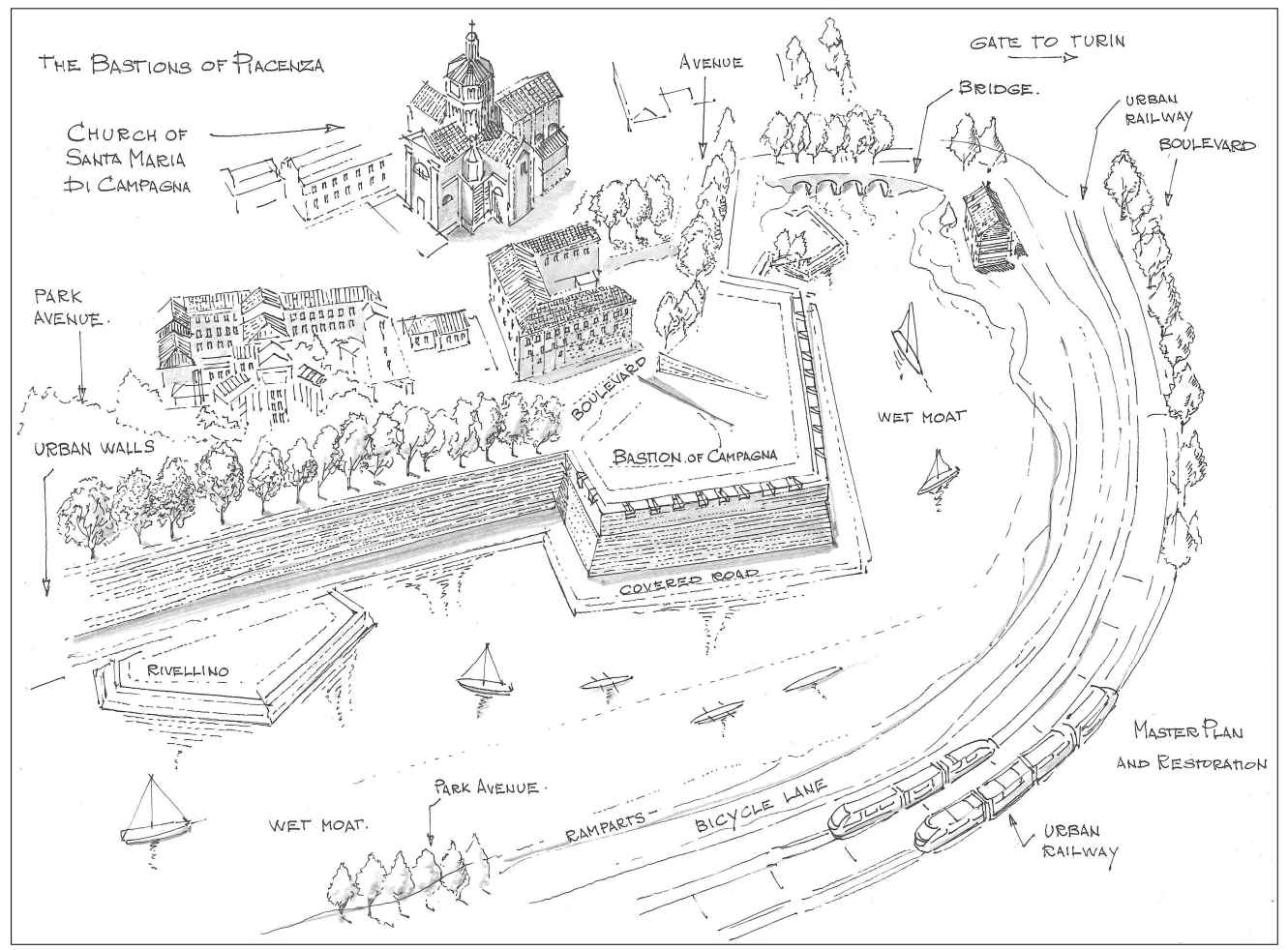

Fig. 1. Bastion of Campagna In Piacenza. Urban project and restoration (Drawing by F.Broglia, 2019). 
The beginning was characterized by the fury of the anti-Austrian revolutionaries, which led to the dismemberment of Duke Pierluigi's castle, the keystone of the system. A magnificent polygon with five bastions still lie mutilated within the Northern Heavy Keeping Pole (military institution for the production and maintenance of war materials). In addition to this once equipped citadel, other sections came under the blows of pickaxes. East need, At the beginning of the twentieth century the East Pole was demolished to make way for the train station and the laying of tram lines.

This action was considered destructive and wicked by scholars and polyorcetic enthusiasts but, nevertheless, today generates anatomical views of overwhelming interest and undoubted beauty. A number of bastions were subjected to partial dissection: once the embankments had been removed, the curtain walls remained.

The inside view of the latter reveals wise Sangallesque theories with a continuous series of discharge arches. Horizontal rows of bricks and round-headed bricks ascribe constructions to a crucial period of Renaissance fortification. Where the structures remain intact, the guns and their posts disappear to make way for placid avenues flanked by plane trees. This is the latter the case of the Public Walk, the so-called "Facsal" distortion in the Piacenza dialect of the English "Vauxhall". Ironically, part of the railways inside and outside the town, whose walls were demolished, were in turn dismantled in the decades after the Second World War.

\section{History, Memory, Urbanism}

In the present state of affairs, the tree-lined street in the former fortified squares is pleasant but unfinished. It could embrace the city, surrounding it with a healthy green belt. Instead, it concerns only a part of the walled enclosure. The latter, although devoid of important features, is still in need of urgent restoration and remains a homogeneous complex of considerable historical importance. Most of those who pass by it every day gaze at it with indifference. It is a silent curtain

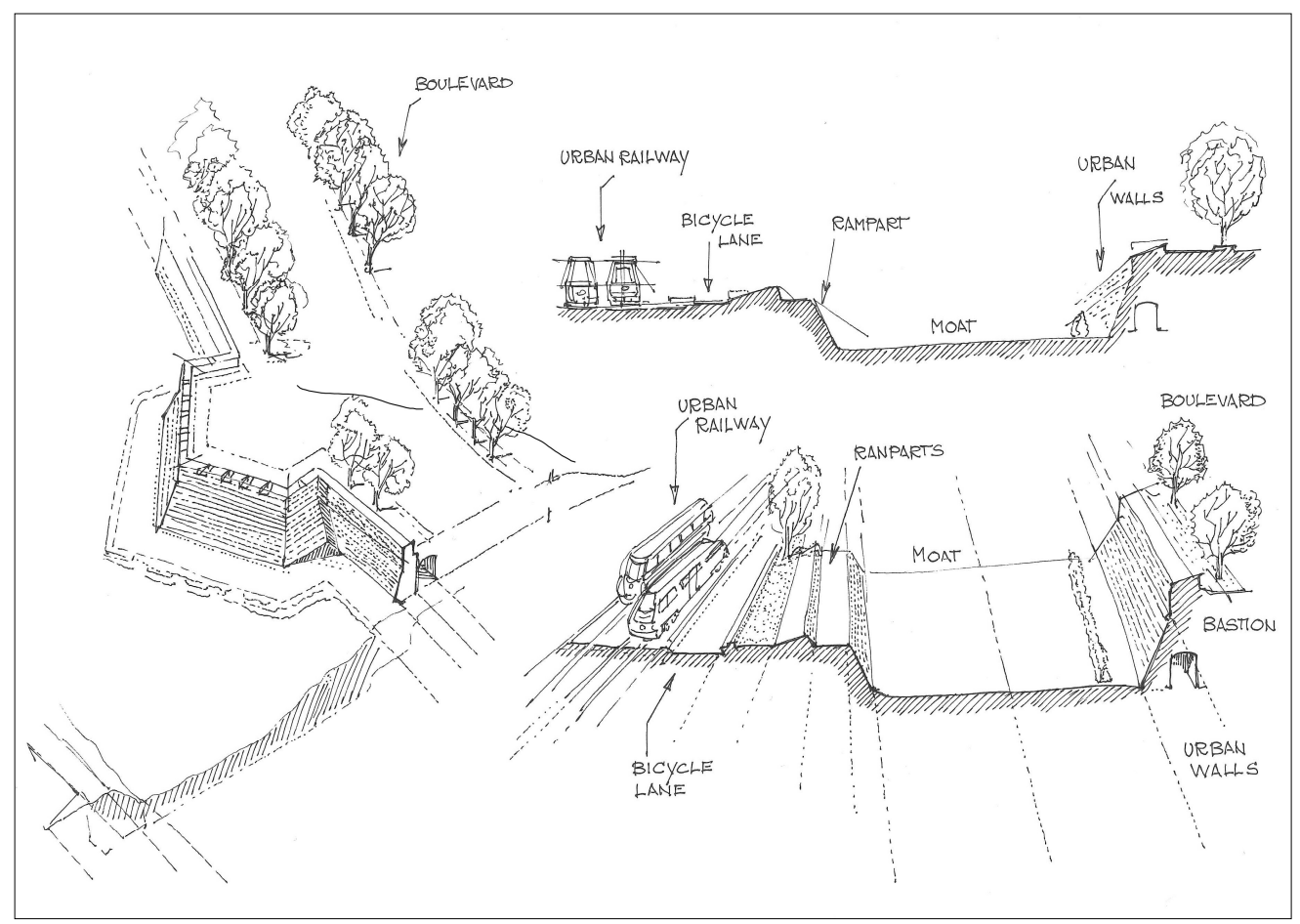

Fig. 2. The Bastions of Piacenza. Urban railway project and restoration (Drawing by F. Broglia, 2019). 
which, on the contrary, should tell its own story through its own urban image as a useful protagonist of the current building fabric.

Built by Clement VII, Pope of the Medici, and completed by the son of Pope Paul III Farnese, Duke Pierluigi, who completed it with a mighty fortress, the Renaissance perimeter wall is still largely equipped with town gates, ramparts, complete with shoe, redondone (Broglia, 2018), traces of the cannon supports, moats ${ }^{5}$. The terraces, the position of the covered road and perhaps the half-moons with the rivelins could be identified in several parts with attention (Artocchini, 1983). Ad hoc archaeological excavations would be useful for this. The theme of which river fed the mirrors of water at the foot of the walls is worthy of further study. The currents of the Trebbia or those of the Po? Both? The fact remains that the waterway, (the great River Po in particular), was much more important in the Renaissance than it is today. It meant that Piacenza, an inland town in Emilia, was a European cross- roads in the Mediterranean. Such a relationship with the river must be recalled and recovered in a modern key. Today, the streets of earth and the ribbons of asphalt which dominate their surroundings especially towards the north, constitute an effective cover separating the historic town from its ancient territory. In the sixteenth century (and until the beginning of the last century) the Po could be observed from the ramparts. Tumultuous industrial development definitively separated the old town from the countryside and hid the river.

The deck of a large viaduct for car traffic completely covers the view of the embankments, along with other infrastructure (industrial buildings, power stations and cement factories ... and so on). The inhabitants of the current Lombard plain have become the population of an immense and widespread town, which from Turin reaches Bologna and the Adriatic Coast without interruption. In this context, the "fast" movement of people and goods takes place mainly by road.

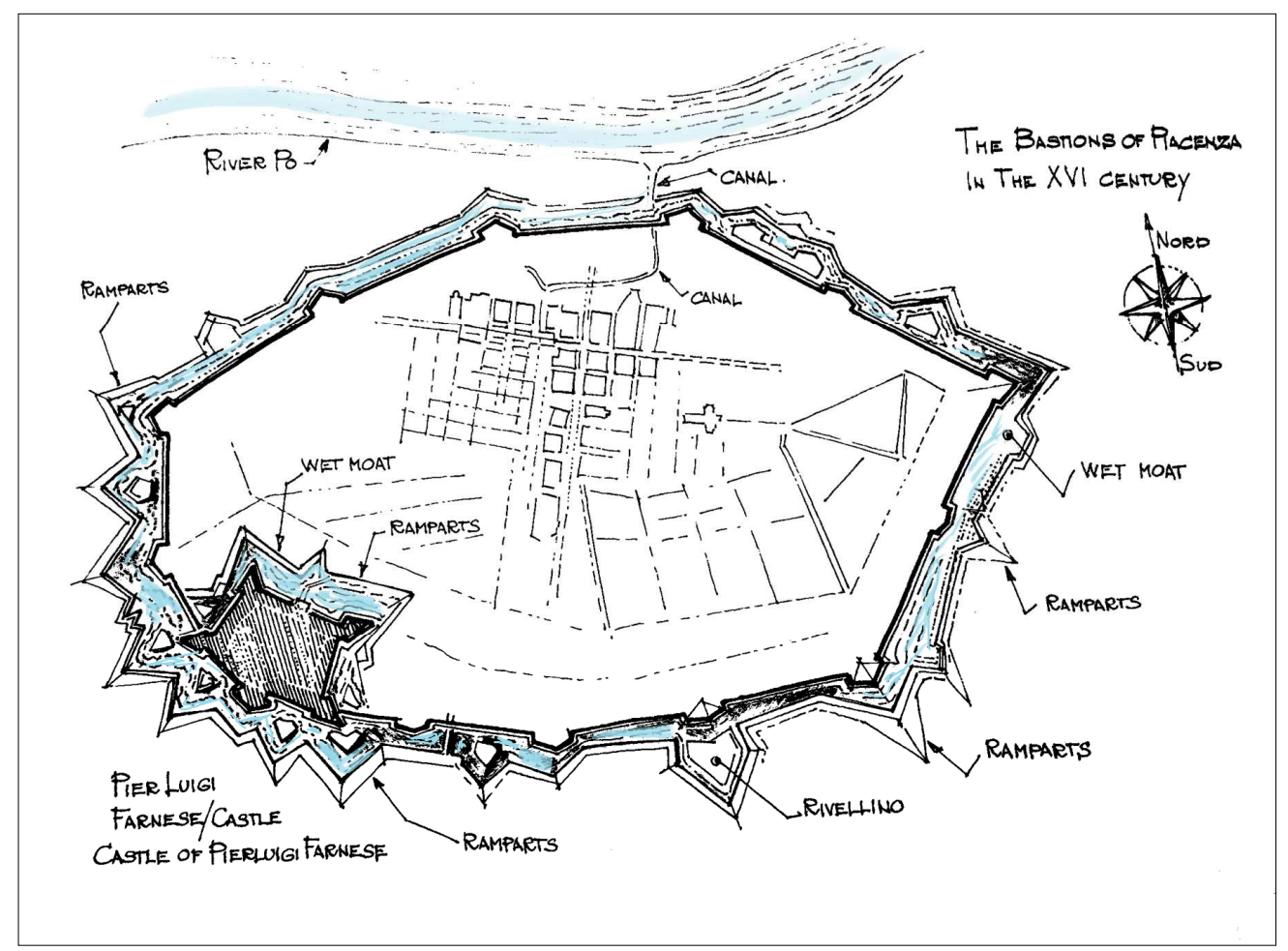

Fig. 3. The Bastions of Piacenza in the sixteenth century (Drawing by F. Broglia, 2019). 
Even people have left the original urban centers to settle in the territory, in suburbs with low population density. In this way, the distances between production centres and residences have increased.

The spaces of the poles where goods and services are exchanged have moved beyond the town walls. Within these walls have remained places of memory and historical collective identity. In this way, a good deal of real life takes place beyond the ramparts, while within their circle, representative and cultural places remain, except for what remains of today's military installations. Since the unification of Italy, these have seen the proliferation of factories and barracks around a large part of the Renaissance line of defence.

The walls, however, have been usefully incorporated into the military establishments. It was only in the 1990s, at the behest of some officers and executives, that the restoration of the walls began to be seriously assessed, considering their documentary and demo-ethno-anthropological value. $^{6}$

\section{The walls' transformation into Museum}

The walls therefore have to be made into a museum, re-integrating them within the existing town as part of a precise urban plan. They are to become an educational path and, at the same time, a railroad system immersed in greenery and dedicated to sustainable mobility.

To plan such an intervention, it is necessary to start from the technical data inherent to the ancient fortifications. In the high squares, general restoration and restoration in particular of the gun supports is considered to be imperative, with the installation of real models of sixteen century artillery, with a gun-fortified fortress. Wherever possible, the internal passages, i.e. the "traitor" positions, protected by "mump" sides and counter chambers, should be accessible and open to

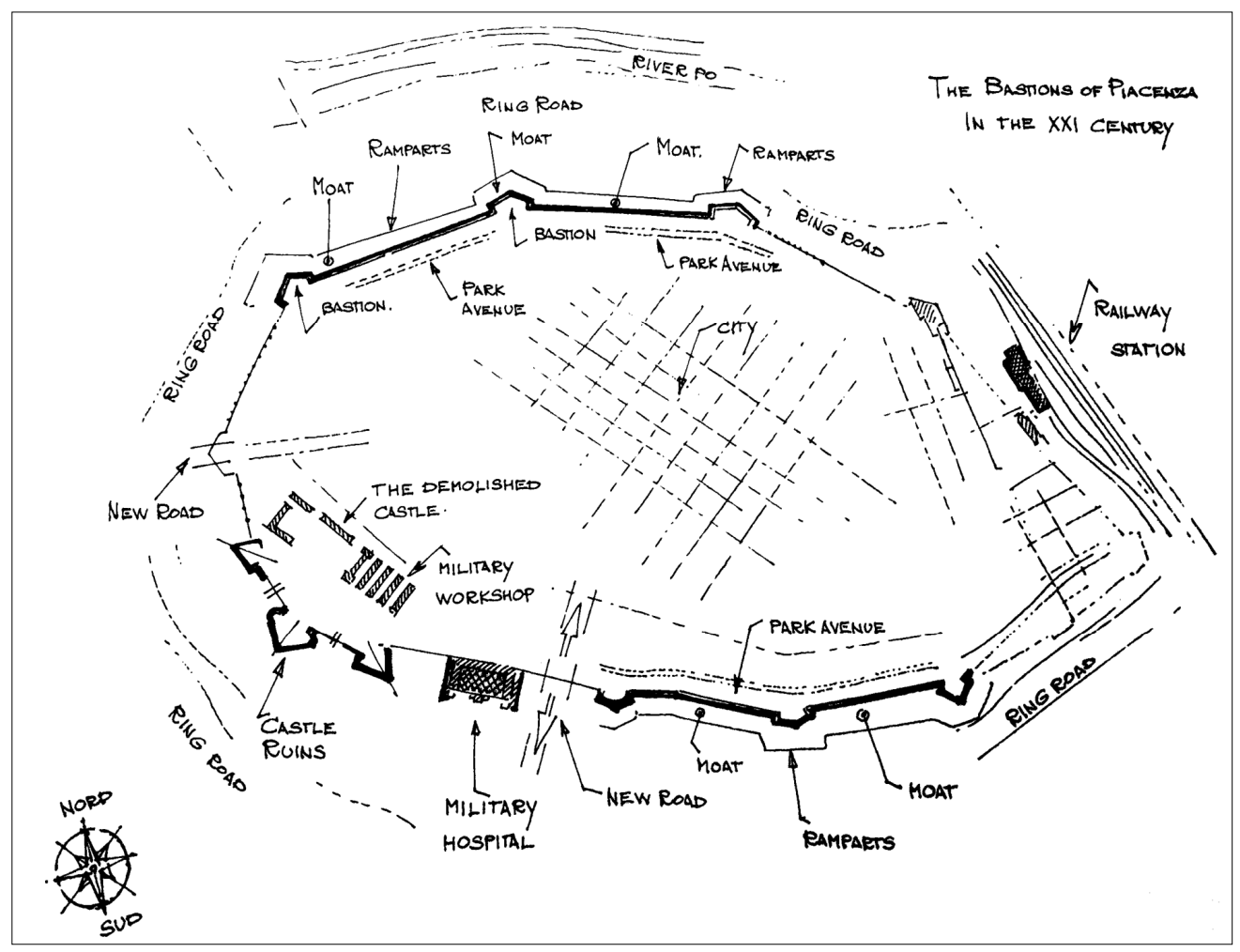

Fig. 4. The Bastions of Piacenza in the twenty-first century (Drawing by F. Broglia, 2019). 
visitors. In the latter there are several wall fabrics with bricks of different quality.

The changes in the degree of firing and consistency of the bricks have been attributed by local experts to the poor arrangement of the Piacenza brick factories to fulfil the wishes of Duke Pierluigi who, in order to build his fortress, had burdened the nobles and the people with decrees and taxes. In reality, the clay mixtures of various shapes and consistencies could be ascribed to a system of absorption with variable deformation of enemy artillery shots.

Throughout the perimeter, particular attention should be paid to the restoration of the external curtains, which were in poor conditions. They are decaying, mainly due to biological factors (uncontrolled growth of plants by anemophilous pollination) and physical conditions (i.e. frostbite). The escarpments, the redondone and the perpendicular summits have to be reintegrated. The profiles need cleaning in order to be legible again. By tradition and by treatise, the artillery pieces on the highest lines were called in barbetta (because of the endemic presence of grass on the edge of the gun supports), but periodic maintenance would limit pariethyria, capers and other tenacious roots of higher plants.

Another important issue to consider is the treatment of ditches. Where they are still visible and dry, it is possible to investigate their section carefully, so to depict the original profile, its covered road, wide riverbed, rivulet or whip in the middle and terraces. They could be wettened, at least in some sections, by means of appropriate hygienic and sanitary treatment and the canonical regimentation of water. In this way, the image would be reintegrated with the necessary critical spirit, suggesting to the visitor the essential parts of the fortress.

The advantage this proposal in just a few sections is twofold: there could be special water basins to be maintained and filled periodically, while on the "dry" parts there would be hedges (to simulate the "covered road" at the foot of the ramparts), promenades, "slow" bike lanes, where the anatomy of the ancient fortified system could be observed, in its ideal "section". A separate matter are the series of arches (brought to light by old excavation works) on the back of the fronts of the walls whose creator was Antonio da Sangallo.

He figured out an apparatus of differentiated resistance. The bricks of the curtains, of some parts of the countermine chamber and of the backstays were placed according to their material resistance to the kinetic energy of the enemy cannonballs. It was an apparatus with variable deformation and breakage, to dampen the effects of enemy blows. Round rings with brick feet completed the system. It was not a continuous masonry, placed behind the curtain, but a line of supports (difficult to hit all together at the same time), so to avoid complete collapses by the besiegers' artillery shots.

A similar frame, which came to light thanks to the abovementioned demolitions, today offers itself as a historical ornament of a public avenue. An aesthetic, playful and didactic path of great interest. Totemic signs and references, both graphic and digital, can explain the origin and the reasons why the wall presents such a structure. This is valid for the whole perimeter wall. In developing the fortified belt, Antonio da Sangallo translated his thoughts into practice, defining Piacenza as a prototype of the Renaissance technique. Where the stretches of the curtain are longer, between two bastions, he still turned to the artifice of the "cavaliere". This is a rise in clay, or a brick formwork according to some scholars, above the edge of the walls where the batteries of cannons were located.

However, we should look for traces of these ancient parts of the wall system since today they are longer visible (except for ancient views or landscapes). It would be a good idea to make them raised panoramic viewpoints.

\section{The urban mobility meta-project and the green belt}

So far, it has been briefly seen how fortification can tell its own story, underlining its main features. In this way, it would once again become a point of reference in the existing urban fabric.

However, what has been described in the previous paragraphs would not be enough to make the 
wall system a "living monument"" . What would make the difference, and what would allow us to use the expression "living monument" (Sette, 2001) is a project of restoration and transformation into a museum, which would match with a wide-ranging urbanistic operation. The public promenade has to cover the entire perimeter of the walls. Walkways are to include observation points for the entire monument and its details. A mainly open-air exhibition, which allows visitors to appreciate the monument in its entirety and its Renaissance allure. In such a way, it would become also an educational and recreational system at the service of the city and of its mobility. It is surprising to see how many activities can be carried out on an ancient fortified wall, recreating a link with the urban fabric. From a structure created to divide and deter enemy, the urban belt can become a device designed to accommodate tourists, visitors, and citizens. In other terms, a place to locate services for health, like a park, and urban mobility. A double-track city rail, where trains run clockwise and counterclockwise, would become a "ring" around the oldest core of the city, to meet the needs of residents, students and tourists. Such a scenario would allow: 1) the historical ramparts to be restored and opened to the public (thrones, curtains, redondone, shoe, covered road, moat, cavalieri, rivulets and crescents); 2) a fast bike lane to run beyond the stands, and 3) a city rail to travel two-way. This would permit the development of an integrated urban system, where the ancient motionless defence machine would act as a recreational-didactic park, with linden and plain trees, hedges to simulate the ancient covered roads, and water basins that create the ancient moat, at least in a few parts. Drawing the section of such an apparatus suggests that historical goods and contemporary needs can coexist in harmony.

\section{Notes}

1 The physical limit of Emilian Renaissance towns, namely their walls, is a theme that has been discussed by experts such as Carmen Artocchini, Carlo Perogalli, Antonio Cassi Ramelli, e Valeria Poli (just to mention a few) over the years.

2 The invention of the bastion matches the emergence of firearms and the birth of the Renaissance principality in the sixteenth century.

${ }^{3}$ See the Expansion Plan (1859) for Barcelona

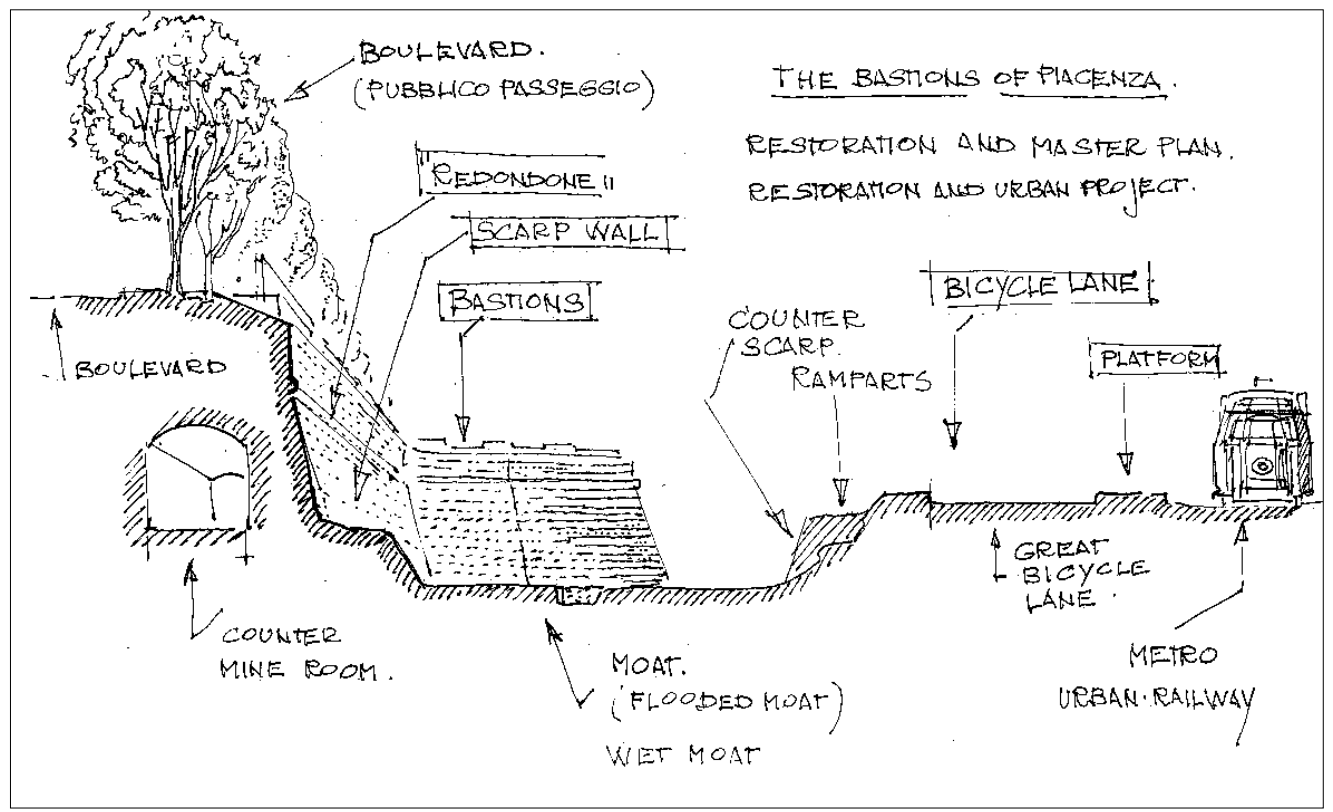

Fig. 5. Ideal section Urban Project. Bastions of Piacenza (Drawing by F. Broglia, 2019). 


\section{by Ildefonso Cerdà.}

${ }^{4}$ The space behind the walls and the embankment.

${ }^{5}$ The section of the bastioned walls of Piacenza is an emblematic example, as it is equipped with all the characteristic components of the sixteenth century fortification, with wet moats.
${ }^{6}$ The acts of the Commission of Inquiry for the Protection and Enhancement of the Historical, Archaeological, Artistic and Landscape Heritage, for the Salvation of Cultural Heritage in Italy, 1967, are explicitly mentioned.

7 "A living monument", in the sense of the theory of restoration, i.e. one that is still alive today.

\section{Bibliography}

Artocchini, C. (1983). Castelli Piacentini, Edizioni TEP, Piacenza.

Broglia, F. (2018). "Renaissance Fortification in Piacenza: the meeting point of Mediterranean Sea and Northern Europe", in Marotta, A.; Spallone, R., eds., FORTMED 2018. Defensive architecture of the Mediterranean, pp. 465-470.

Cerdà, I. (2004). Teoria generale dell'urbanizzazione, Antonio Lopez De Aberasturi Ed., Jaca Book, Milano.

Hogg, I. (1982). Storia delle Fortificazioni, Istituto Geografico De Agostini Ed., Novara.

Poli, V. (2016). La storia urbana di Piacenza: il sistema fortificato, L.I.R. Ed., Piacenza.

Sette, M.P. (2001). Il Restauro in Architettura, Utet Ed., Torino.

VV.AA. (2017). Piacenza dall'alto - i caratteri originali l'evoluzione secolare, la forma attuale, Tip.Le.Co. Ed. 